\title{
Design and manufacture of a coronary stent INC-1 and initial tests in experimental animal model
}

\author{
Diseño y fabricación del stent coronario INC-1y pruebas iniciales en animales de \\ experimentación
}

\author{
Arturo Abundes-Velasco', Gian M. Jiménez-Rodríguez², José L. Romero-Ibarra ${ }^{3}$, Juan P. Sandoval-Jones², \\ Efraín Sánchez-Pérez ${ }^{1}$, Ramsés Galaz-Méndez ${ }^{4}$, Paola Ulacia-Flores ${ }^{4}$, Julio I. Farjat-Pasos², \\ Jorge Padilla-lbarra², Sebastián Aceves-Díaz González¹, Marco A. Martínez-Ríos², Marco A. Peña-Duque ${ }^{1 *}$, \\ and David A. Rodriguez-Parra ${ }^{1}$
}

${ }^{1}$ Subdirectorate for Innovation and Development Projects, Instituto Nacional de Cardiología Ignacio Chávez, Mexico City; ${ }^{2}$ Department of Hemodynamics, Instituto Nacional de Cardiología Ignacio Chávez, Mexico City; ${ }^{3}$ Department of Interventional Cardiology, Hospital Star Médica Querétaro, Querétaro; ${ }^{4}$ General Directorate and Department of Biomedical Engineering, GSE Biomedical, Hermosillo, Sonora, Mexico

\begin{abstract}
In this paper, we describe our coronary stent (INC-1) design and development, the way that we found the specific characteristics needed for our device including biophysics aspects, design, finite element testing, manufacturing, and mechanic trials, we submitted and animal models experiences. The stent platform was cobalt-chromium L605 (Co-Cr), with struts thickness of $80 \mu \mathrm{m}$, balloon expandable. We placed the coronary stent INC-1 on a rabbit and dog models so we can evaluate efficacy and security of the device in relationship to its biomechanical properties including navigation capacity, traceability, symmetric expansion, and safety, as well as endothelial attachment, thrombogenicity, and lack of involvement of secondary branches in these models. We succeeded in efficacy and safety of the device after fluoroscopy-guided implant proving excellent capacity of release system, traceability, fluoroscopic visualization, symmetric expansion, and complete endothelial attach. Furthermore, we obtained a good post-implant balloon withdrawal, functional integrity, and no vascular complications. We observed adequate clinical evolution 3 weeks after the stent implantation.
\end{abstract}

Key words: Stent. Novel bare metal stent. Myocardial infarction. Percutaneous coronary intervention.

\section{Resumen}

En esta publicación se describen el diseño y el desarrollo de un stent coronario (INC-1), la forma en que se determinaron las características biofísicas deseadas, el diseño y las pruebas computacionales por elemento finito, su fabricación, así como las pruebas mecánicas a las que se sometió el prototipo y por último las primeras experiencias en modelos animales. La plataforma del stent desarrollado fue de cobalto y cromo L605 (Co-Cr), con struts de 80 um de grosor, expandido por balón.

Correspondence:

${ }^{*}$ Marco A. Peña-Duque

E-mail: marcopduque@gmail.com
Date of reception: 28-05-2019

Date of acceptance: 10-12-2019

DOI: $10.24875 /$ ACME.M20000108
Available online: 04-09-2020 Arch Cardiol Mex (Eng). 2020;90(2):142-147 www.archivoscardiologia.com 2604-7063 / @ 2019 Instituto Nacional de Cardiología Ignacio Chávez. Published by Permanyer. This is an open access article under the CC BY-NC-ND license (http://creativecommons.org/licenses/by-nc-nd/4.0/). 
La colocación del stent coronario INC-1 se realizó en un modelo de conejo y uno canino con el objetivo de evaluar el éxito técnico y de seguridad del stent en relación con las propiedades biomecánicas (capacidad de navegación, maniobrabilidad, expansión simétrica del stent) y de seguridad (fijación a la pared vascular y ausencia de compromiso de ramas secundarias y formación de trombos en el momento de la colocación del stent en el modelo animal). Se obtuvo éxito técnico y de seguridad del stent después del implante guiado por fluoroscopia, lo que demostró adecuada capacidad del sistema liberador, excelente maniobrabilidad, adecuada visualización fluoroscópica, expansión simétrica y fijación completa a la pared vascular, capacidad para retirar el balón desinflado después del implante, e integridad funcional y sin complicaciones vasculares. La evolución clínica fue favorable a tres semanas del seguimiento planeado.

Palabras clave: Stent. Nuevo stent metálico. Infarto de miocardio. Intervención coronaria percutánea.

\section{Introduction}

Worldwide, 5.4 million new cases of cardiovascular diseases are diagnosed, most of them related to coronary artery atherosclerosis, and cause more than half a million deaths annually and an economic expenditure of billions of dollars ${ }^{1}$. The outlook in Mexico is not different, and ischemic heart disease is estimated to have $1 \%$ annual incidence in patients aged $45-54$ years and $4 \%$ in individuals aged $75-84$ years $^{2}$; in addition, it is the leading cause of morbidity and mortality.

The role of coronary stents in the treatment of ischemic heart disease, both in its acute and chronic behavior, is now well established, and it is currently the most common modality for the performance of coronary artery bypass graft ${ }^{3,4}$.

The application of coronary interventionism as therapeutic behavior for ischemic heart disease has been limited in this country. According to the Organization for Economic Cooperation and Development (OECD), Mexico ranked last in the use of this resource among the 35 OECD member countries in 20135; furthermore, the results of the national registries of acute coronary ischemic syndrome (RENASICA - Registros Nacionales del Síndrome Isquémico Agudo) I, II, and III ${ }^{6-8}$, which have included 20,647 patients, have shown that the use of this therapeutic resource only occurs in $29 \%$ of them, which is attributed to the high cost of the required supplies (stents, fluoroscopy room, etc.), among other factors, and the health expenditure deriving from the use of this therapeutics is high and thus this need cannot be adequately covered.

Mexico has a considerable lag in science and technology investment, calculated at approximately $0.44 \%$ of the gross domestic product (GDP); in the USA, expenditure in relation to the GDP is $2.79 \%$. This is reflected on lack of development and technological dependency, and thus, there is an urgent need to improve this gap that actually accentuates inequality ${ }^{9}$.

\section{Materials and Methods}

\section{Phase I: Desired characteristics and initial design}

The design and development of the INC-1 coronary stent started in late 2014 at the National Institute of Cardiology, in association with GSE Biomedical and the Monterrey Technology and Higher Education Institute, with the support of CONACYT. To that end, a multidisciplinary group was formed, weekly meetings were punctually arranged (a total of 12), where specific tasks and technical requirements were resolved, with methodology being used as a guidance based on quality function deployment (QFD) ${ }^{10}$; with this tool, the needs of the "customer," in this case interventional cardiologists, were confronted against technical or engineering requirements and limitations and were compared with the maximum objective to be achieved, after taking into account, the biophysical characteristics of state-of-the-art commercial stents. Among the requirements requested by the "customers" or interventional cardiologists, the following stood out: low mechanical fatigue, little or no corrosion, no ionic release, magnetism or favorable hydrophobicity, zero galvanic effect, flexibility and maneuverability, low profile, sufficient radial force, minimal longitudinal shortening, uniform radial and longitudinal expansion, easiness for mounting, appropriate cell area for drug release, minimal surface area, high biocompatibility, and minimal cell proliferation.

The characteristics the INC stent should have were agreed: L605 cobalt and chrome (Co-Cr) platform, in accordance with the international standard [(Standard Specification for Cobalt-28 Chromium-6 Molybdenum Alloy Castings and Casting Alloy for Surgical Implants (UNS R30075)], with $80 \mu \mathrm{m}$ thick struts, balloon expanded and with equal or higher performance than second-generation stents, depending on the requirements of standard ISO 25539, vascular stents ${ }^{11}$. 
CAD drawings of the different design iterations were carried out using the SolidWorks program, in addition to multiple tests, until the most suitable model for the requested needs and requirements was defined before manufacturing; finally, a balance of the most favorable values with regard to radial force, flexibility, and longitudinal deformation, among others, was found.

\section{Phase II: Prototypes and physical tests in vitro}

Thirty stents were manufactured in an FDA-certified laboratory by laser cutting on an $80 \mu \mathrm{m}$ thickness Co$\mathrm{Cr}$ L605 tube, with the final design specifications (Fig. 1); passivation and electropolish treatment were carried out. With 15 pieces, in vitro tests were carried out in accordance with the ISO standard (evidence folder is available) ${ }^{11}$ :

1. Post-expansion length change.

2. Longitudinal diametrical uniformity.

3. Uniformity of stent struts expansion, interconnecting beams behavior, in comparison with those obtained in the computer simulation.

4. Diametric compression test between parallel plates or radial force and comparison with different commercial stents according to ISO 25539-2 standard ${ }^{11}$ (Fig. 2).

5. Longitudinal compression test.

6. Migration test.

\section{Phase III: Start of the experience on animal phase}

At this initial stage, a preliminary test of the stent was carried out in two animal models (one in rabbit and one canine) to assess safety and efficacy; a protocol was subsequently conducted in pigs with clinical, angiographic, and intracoronary ultrasound follow-up of 4-6 months, with adherence to the guidelines established by the institutional bioethics committee and international standards for the use and care of experimental animals $^{12-15}$.

Based on the above, the INC coronary stent was placed on a New Zealand breed rabbit model of $4.4 \mathrm{~kg}$ in the abdominal aorta and in a $22 \mathrm{~kg}$ canine model of the Nahuatl breed in the right renal artery. The purpose was to assess technical success regarding the following biomechanical properties: navigation capacity, maneuverability, symmetrical expansion of the stent, adequate fixation to the vascular wall, no compromise of secondary branches, and ease of balloon removal;

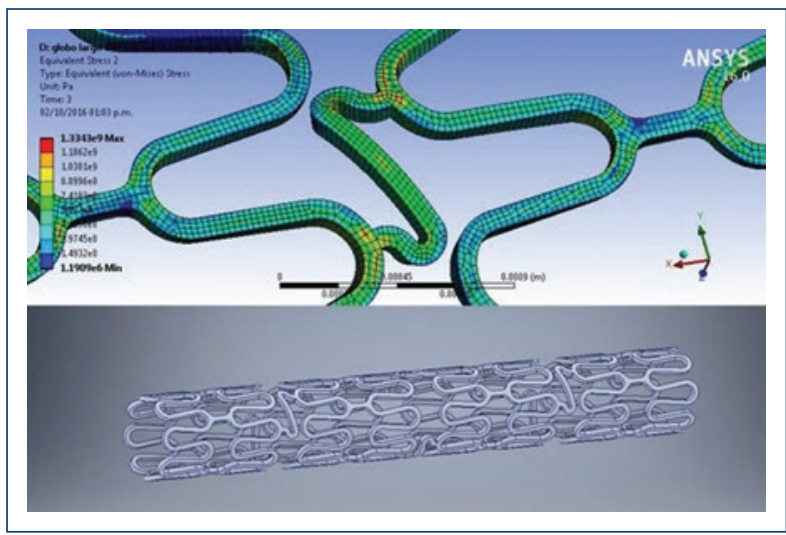

Figure 1. The image on top shows the finite element structural analysis (numerical model for structural analysis of the coronary stent deformation plasticity). The image below shows the stent final structural model.

in addition, safety of the latter was assessed with regard to vascular integrity, blood flow quality, thrombosis, and involvement of secondary branches. The recommendations of the preclinical stent evaluation consensus were taken into account ${ }^{16}$.

\section{Technical procedure}

The procedure was carried out at the experimental surgery laboratory of the animal care facilities of the National Institute of Cardiology in an operating room that has a portable fluoroscopy equipment (Siemens Arcadis Varic, model 08677051), with care for asepsis, antisepsis, and balanced general anesthesia (propofol and isoflurane), through a percutaneous femoral approach in both models with a $4 \mathrm{Fr}$ introducer for the rabbit and $6 \mathrm{Fr}$ for the dog; angiograms were obtained to define the stent diameters; then, the biomechanical properties of the stent were assessed to determine its technical and safety success, and a $3.0 \times 20 \mathrm{~mm}$ INC stent was implanted in the rabbit's abdominal aorta and one measuring $3.5 \times 20 \mathrm{~mm}$ in the dog's right renal artery. A control angiography was obtained, in addition to intravascular ultrasound (Boston OptiCross tube Scientific), from the canine model renal artery stent and, in both, clinical follow-up for 3 weeks was established.

\section{Results}

Efficient and guided processing was achieved using the QFD of INC-1 stent desired foundations. Regarding 


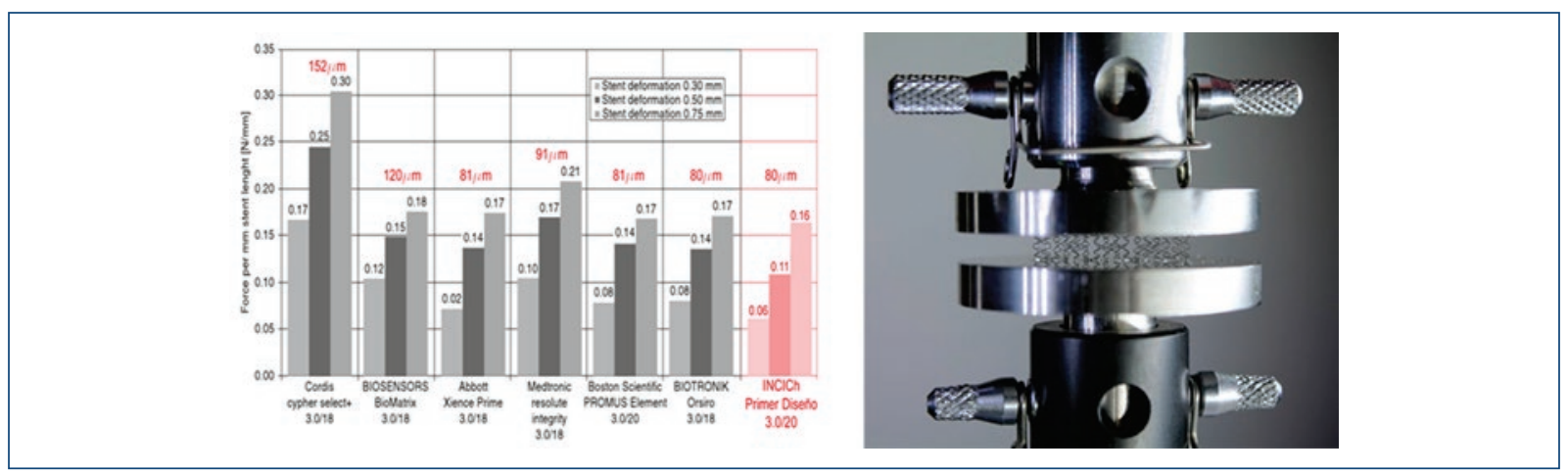

Figure 2. Comparison of the performance to diametric compression between parallel plates (radial force) and those reported with commercial stents and those obtained for the INC stent.

the results for mechanical behavior (radial force, flexibility, deformation to elongation, and longitudinal shortening, among others), the stent showed characteristics that were highly adequate and consistent with the virtual computational tests evaluated using finite element. (The full results of computational and mechanical tests, under the guidelines of the ISO 25539-2 standard, were the deliverables of a GSE project supported by CONACYT's innovation stimulus program, whose evidence folder is available).

In both models (rabbit and canine), by means of the fluoroscopy-guided implant, satisfactory technical success was demonstrated in all assessed parameters, among them an adequate capacity of the releasing system to reach the implant site by percutaneous approach, and achievement of adequate maneuverability and acceptable fluoroscopic visualization, with efficacious and accurate release at the implant site, which confirmed symmetrical expansion and complete fixation to the vascular wall. In addition, a satisfactory result was obtained in terms of safety, since in both models was the treated vascular anatomy respected, with its integrity being preserved, without extravasation, with normal final angiographic flow, and no evidence of thrombi (Fig. 3A).

Intravascular ultrasound (OptiCross probe, Boston Scientific) applied to the canine model renal artery stent, corroborated adequate expansion and fixation of the stent to the vascular wall, symmetry in three analyzed segments, and consistent diameters achieved with the selected balloon diameter of $3.5 \mathrm{~mm}$ (Fig. 3B).

\section{Discussion}

Coronary artery interventionism with stent placement has been shown to be a safe and efficacious

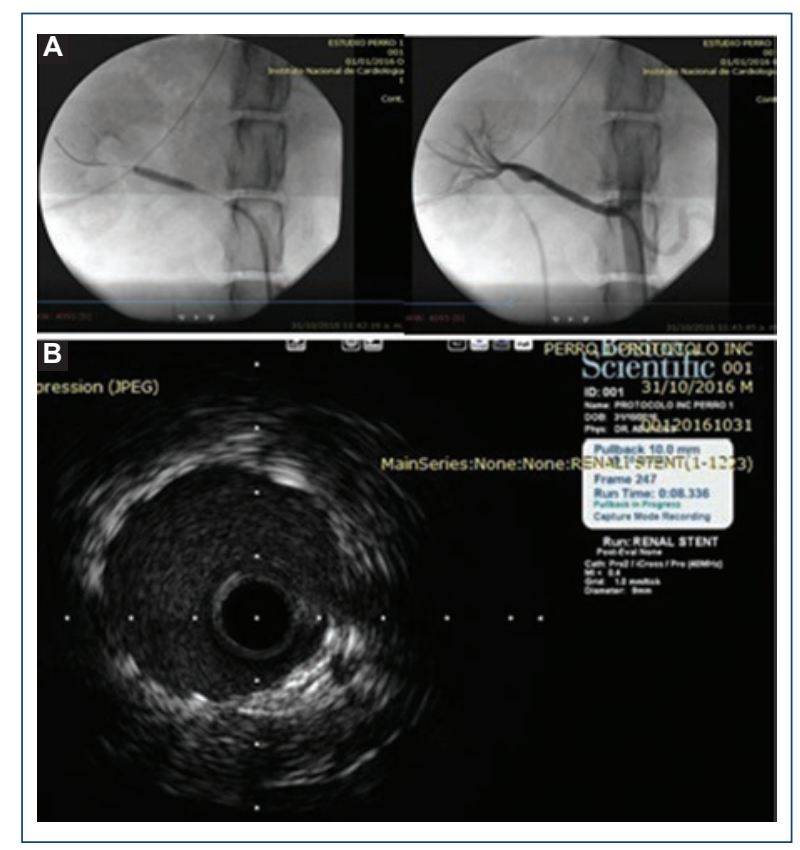

Figure 3. A: Fluoroscopic image of stent release over the balloon in the dog's right renal artery and final angiographic image with an optimal result. B: Ultrasound image with adequate apposition, fixation, and expansion results.

procedure in the treatment of ischemic heart disease due to coronary artery atherosclerosis, which is the most common cause of worldwide disability and mortality ${ }^{17}$. This project has been devised with the purpose of having a national technology development that promotes not only the obtainment of a more accessible product for the Mexican population but also innovation and less dependence on foreign technology.

The objectives of the National Institute of Cardiology are based on the principles of assistance, education, 
research, and technological development, outlined since its foundation by doctor Ignacio Chávez. Based on these needs, the Sub-directorate of Innovation and Technological Development has been created in the institute.

There are precedents of stent development in Mexico ${ }^{18-20}$; however, technological improvement has been highly important in recent years, and thus, currently, there are recommendations and requirements for design and computational, mechanical, and preclinical tests that ensure the best clinical results ${ }^{16-21}$.

In accordance with the above, carrying out this project to design, manufacture, and test, a coronary stent with all the modern recommendations is fully justified; in a second stage, efforts will be merged with institutions or companies to develop this project for industrial and commercial production, in such a way that patients, the institute, Mexican companies and the country are benefited, both for the decrease of technological dependence from abroad and for the creation of new jobs and development of qualified human capital. Hence, a virtuous circle will be created based on this program, and the coronary stent will, therefore, be the first of other technology projects to be developed in the area of cardiovascular health.

An accurate and detailed description of engineering processes (design, finite element testing, etc.) was not included for the purposes of this publication, only the most important aspects of this area for medical knowledge; such results were provided in detail to CONACYT (there is a folder of evidence available), which justified the engineering procedures used for this project.

\section{Conclusion}

This document described how the INC-1 stent was conceived and manufactured, the first tests of which were carried out satisfactorily. The purpose was to develop technological resources of our own at the National Institute of Cardiology, to benefit a growing population of patients with ischemic heart disease. That is why a metallic coronary high-tech stent has been developed, with quality material and certification for medical use and a novel cell design. The next step is development of a drug-eluting stent.

It is essential for this device to be tested in a sufficient number of experimental animals, whose model can be comparable to the human being to obtain clinical and statistical validity and guarantee its safe use; later on, developing a protocol in human subjects according to international ethical and scientific standards will be possible ${ }^{22}$.

\section{Funding}

Funding for this work was received through the GSE company, supported by CONACYT's innovation stimuli program.

\section{Conflicts of interest}

All authors declare that they have no conflicts of interest.

\section{Ethical disclosures}

Protection of people and animals. The authors declare that the procedures followed were in compliance with the ethical standards of the responsible human experimentation committee and in accordance with the World Medical Association and the Declaration of Helsinki.

Confidentiality of data. The authors declare that they have followed the protocols of their work center on the publication of patient data.

Right to privacy and informed consent. The authors declare that no patient data appear in this article.

\section{References}

1. OMS/WHO2011: http://www.who.int/whosis/whostat/ES_WHS2011_Full. pdf?ua $=1$.

2. WHO noncomunicablediseases: http://apps.who.int/iris/bitstream/10665/ 128038/1/9789241507509_eng.pdf

3. Patel MR. ACC/AATS/AHA/ASE/ASNC/SCAI/SCCT/STS 2017. Appropriate use criteria for coronary revascularization in patients with stable ischemic heart disease. JACC 2017;69(17):2212-2241.

4. Martínez Ríos MA, coordinador. Infarto agudo del miocardio: documento de postura. Academia Nacional de México: Intersistemas, 2014

5. "Cardiac procedures", in Health at Glance 2013: OECD Indicators, OECD Publishing. http://dx.doi.org/10.1787/health_glance-2013-37-en).

6. Por el Grupo Cooperativo RENASICA. Arch Cardiol Mex. 2002; 72(Supl. 2):S45-S64.

7. García-Castillo A, Jerjes-Sánchez C, Martínez Bermúdez P. RENASICA II. Registro Mexicano de Síndromes Coronarios Agudos. Arch Cardiol Mex. 2005:75(Supl. 1):S6-S19.

8. Martínez-Sánchez C. Clinical management and hospital outcomes of acute coronary syndrome patients in Mexico: The Third National Registry of Acute Coronary Syndromes (RENASICA III). Arch Cardiol Mex. 2016. http://dx.doi.org/10.1016/j.acmx.2016.04.007).

9. Maravert AMI, Molina HJA, Molina RJA. El gasto en investigación y desarrollo experimental (GIDE) en México, promotor del crecimiento económico. (Spending on research and experimental development, promoter of economic growth). https://www.uv.mx/iiesca/files/2016/11/11CA2 01601.pdf

10. What is quality function deployment (QFD)? https://asq.org/quality-resources/qfd-quality-function-deployment.

11. ISO 25539-2:2008 Cardiovascular implants-Endovascular devices-Part 2 : Vascular stents. https://www.iso.org/standard/35887.html

12. Guía para el Cuidado y Uso de los Animales de Laboratorio. Institute of Laboratory Animal Resources Commission on Life Sciences National Research Council. National Academy Press, Washington, D.C. 1999. 
13. Norma Oficial Mexicana NOM-062-ZOO-1999, Especificaciones técnicas para la producción, cuidado y uso de los animales de laboratorio.

14. Ley de protección a los animales del Distrito Federal. Publicado en la Gaceta Oficial del Distrito Federal del 26 de febrero de 2002.

15. Ley Federal de Sanidad Animal. Nueva ley publicada en el Diario Oficial de la Federación el 25 de julio de 2007, texto vigente. Última reforma publicada DOF 07-06-2012.

16. Schwartz RS, Edelman E, Virmani R, Carter A, Granada JF, Kaluza GL, et al. Drug-eluting stents in preclinical studies updated consensus recommendations for preclinical evaluation. Circ Cardiovasc Interv. 2008; 1(2):143-153. doi:10.1161/CIRCINTERVENTIONS.108.789974.

17. Montalescot G, Sechtem U, Achenbach S, Andreotti F, Arden C, Budaj A et al. 2013 ESC guidelines on the management of stable coronary artery disease: The task force on the management of stable coronary artery disease of the European Society of Cardiology. Eur Heart J. 2013:34(38):2949-3003.

18. Abundes VA, Quintana PG, Navarro RJ, Ledesma VM, Autrey CA. Estudio piloto preliminar en humanos con la prótesis endovascular (stentsaq). Resultados inmediatos y a mediano plazo. Arch Inst Mex Cardiol. 2000;70:377-383.
19. Abundes A, Navarro J, Montoya S, Ledesma M, Farell J. Use of new platinum coronary stent (ATLAS STENT) in 169 nonselected patients with complex lesions: immediate and mid-term results. Cathet Cardiovasc Interven. 2001;53(1):122.

20. Abundes VA, Arizmendi E, Montoya S. Resultados inmediatos y a largo plazo del implante de un nuevo stent coronario de platino (stent Atlas) en pacientes con enfermedad arterial coronaria. Rev Esp Cardiol. 2002;55:1205-1208.

21. Karanasiou GS, Papafaklis MI, Conway C, Michalis LK, Tzafriri R, Edelman ER, et al. Stents: biomechanics, biomaterials, and insights from computational modeling. Annals of Biomedical Engineering 2017; 45(4):853-872. DOI: 10.1007/s10439-017-1806-8

22. Byrne RA, Serruys PW, Baumbach A, Escaned J, Fajadet J, James S, et al. Report of a European Society of Cardiology-European Association of percutaneous cardiovascular interventions task force on the evaluation of coronary stents in Europe: executive summary. European Heart Journal 2015;36:2608-2620. doi:10.1093/eurhearti/ehv203 